DOI:10.32703/2415-7422-2020-10-2-353-367

UDC 51(091)

\title{
Maryam Seyidbeyli
}

Institute of the History of Science Azerbaijan National Academy of Sciences

115, Huseyn Javid Avenue, Baku, Azerbaijan

e-mail: mseyidbeyli@mail.ru

https://orcid.org/0000-0001-6827-5885

\section{Life and activity of Nasir al-Din al-Tusi}

Abstract. At the beginning of the VII century in the political life of the Near and Middle East, fundamental changes have taken place. The Arabs conquered a colossal territory, which included the lands of Iran, North Africa, North-West India, the Asian provinces of Byzantium, most of the former Roman Empire. In the conquered cities of the caliphate, observatories, madaris, libraries were built. At the end of VII century, the first scientific center, an academy, the House of Wisdom, was founded in Baghdad, in which scholars who spoke different languages were assembled. Here the translation and commentary activity were very developed, the main works of ancient thought, such as the writings of Aristotle, Ptolemy were published in the 9th century in the Arabicspeaking world. For two centuries from 750 to 950 years, the works of ancient authors on philosophy, mathematics, medicine, alchemy, and astronomy were translated into Arabic, which indicates the high scientific potential of that time in the East. At the same time, in the XII century, Ibn Rushd composed 38 commentaries on the works of Aristotle, the "Republic" of Plato, the treatise "On the Mind" of Alexander of Aphrodisias, which subsequently had an important influence on the work of Nasir alDin al-Tusi. Thus, this period in the history of Eastern scientific thought is marked by high intellectual potential. To this day, historians of medieval Arabic literature face a sufficient number of difficulties, since the vast majority of manuscripts remain inaccessible to them. The works of many renowned Arab authors of the middle Ages are more than 1000 years old, so it seems obvious that the manuscripts of the vast majority of authors have not survived to this day. The researchers of the history of Azerbaijan and neighboring countries in the middle Ages, with all the variety of available sources on which they rely, still attract little factual material related to the Arabic-language works of the historical and scientific genre. Undoubtedly, a comprehensive study of the entire complex of information of Nasir al-Din al-Tusi on the history of science in Azerbaijan is of great importance.

Keywords: Nasir al-Din al-Tusi; history of science; scientific activity; Maragheh; astronomy 


\section{Introduction.}

There are special periods in the history of the nations when the creative powers of its individual representatives are most vividly and fully realized. In the Middle Ages in Azerbaijan in the XIII-XIV centuries, when trade and crafts were developing in the country, magnificent architectural structures were built (mosques, madrasahs, caravanserais, bridges, baths). In the madrasahs that were opening, along with theology, secular sciences were taught, libraries were completed. The most important place among the cultural achievements of that era is occupied by achievements in the field of writing, in particular, numerous works were created on mathematics, astronomy, medicine, logic, philosophy, fine literature, jurisprudence, poetry and fiction. The purpose of article is to study the life and scientific activity of Nasir al-Din al-Tusi on the basis of historical sources by using comparative method of analysis.

At the beginning of the VII century in the political life of the Near and Middle East, fundamental changes have taken place. The Arabs in a short time conquered a colossal territory, which included the lands of Iran, North Africa, North-West India, the Asian provinces of Byzantium, most of the former Roman Empire. In the conquered cities of the caliphate, observatories were built; libraries were created at palaces, mosques, and madaris. At the end of VII century in Baghdad, the first scientific center, an academy, the House of Wisdom, was founded, in which scholars who spoke different languages were assembled. During this period, the Arabic language became not only the state language of the Near and Middle East, but also the language of science and culture. Here the translation and commentary activity were very developed, the main works of ancient thought, such as the writings of Aristotle, Ptolemy were published in the 9th century in the Arabic-speaking world. In the history of the world's philosophical science, it is known that the peak of Arabic-speaking Aristotelianism was the work of Ibn Rushd, who turned to the study and commenting of Aristotle at the insistence of Ibn Tufail and stimulated the emergence of the interest of Eastern philosophical thought towards Antiquity. For two centuries from 750 to 950 years, the works of ancient authors on philosophy, mathematics, medicine, alchemy, and astronomy were translated into Arabic, which indicates the high scientific potential of that time in the East. Here developed such scientific disciplines as physics, chemistry, mathematics, medicine, astronomy, geography, botany. At the same time, Ibn Rushd composed 38 commentaries on the works of Aristotle, the "Republic" of Plato, the treatise "On the Mind" of Alexander of Aphrodisias, which subsequently had an important influence on the work of Nasir al-Din al-Tusi. Thus, this period in the history of Eastern scientific thought is marked by high intellectual potential.

Thus, this period in the history of Eastern scientific thought is marked by high intellectual potential.

The study of the history of scientific thought of this era and activity of scientists show that Azerbaijani science reached a significant flourishing during this period, marking the processes of the Eastern Renaissance. Significant development is observed in astronomy, astrology, geography, mathematics, geology, engraving, music, etc. in 
the late 13th - early 14th century. In many cities of Azerbaijan, rabats, madrasah, mosque and other structures were built by architects. Maragha and Tabriz were the main centers of the literary and scientific life of Azerbaijan at that time. Scientists from different countries worked in the Maragheh Observatory, even from distant China.

\section{Results and discussion.}

Nasir al-Din al-Tusi.

During the rule of Ilkhanate dynasty, Hulagu Khan (1256-1265) and Abaqa Khan (1265-1282), an outstanding scholar and organizer of science in Azerbaijan, Muhammad ibn Muhammad ibn al-Hasan al-Tusi made a significant contribution to the development of almost all the well-known branches of sciences, which the center for many years became Azerbaijan. Mathematics, ethics, cosmology, mineralogy, trigonometry, geography, history, law, calendars, medicine, education, morality, logic, theology, poetics, calligraphy are not only a complete list of research fields, which are deservedly headed by Nasir al-Din al-Tusi (Bunyatov, 1982a). Nasir al-Din al-Tusi Tusi is from Tus - many historians have spoken about this, one of whom - Hamdallah Mostovfi - reports: "His relatives moved from Sava to Tus and settled here". He says in the preface to his work "Zij Ilkhani": "I am the messenger of God from Tus" (Razavi, 1994, p. 12). Most people called him Khoja Nasir Tusi or Mawlana Nasir Tusi.

This outstanding Azerbaijani thinker and encyclopedic scientist is a unique phenomenon in the history of science of the XIII century. Along with the exact sciences, he deeply studied the problems of philosophy, literature, musicology, aesthetics. He knew Greek science well, was a commentator on the works of Archimedes, Autolycus, Euclid, Theodosius, Minelaus, Apolonius Aristarchus, Hypsicles, Ptolemy and others. Tusi was handsome in person, noble, generous. He was described as a person who possessed patience, faithful in friendship, responsive in trouble, in general - endowed with a huge number of high virtues (Bunyatov, 1982a, p. 70). Ibn al-Fuwati, a disciple of Nasir al-Din al-Tusi, the author of "Talkhis alMajma al-adab fi mujam al-alkab" was with him until the end of his days. He wrote about him as follows: "He is a worthy scientist, generous with a moral, character and good biography" (Razavi, 1994, p. 67).

Tusi wrote a commentary for Avicenna's al-Isharat after Fakhr al-Din al-Razi's commentary and replied to Razi's critique intended against Avicenna's philosophy. Bar Hebraeus translated Al-Isha ra $t$ under the influence of these discussions. In addition, Bar Hebraeus' Book of Ascent of the Intellect was influenced by Tusi 's works on astronomy. However, Bar Hebraeus' special interest in Tusi 's ethical book can be understood from his statements which are found in his Chronicon and Arabic work on history: This year, Nasir al-di n al-Tu si is dead. He had a big observatory in Maragha and also, he worked on all kinds of wisdom. He wrote many books on logic, physics, theology, Euclid and Majesty. In his extraordinarily beautiful ethical book in Persian language, he collected all texts of Plato and Aristotle on practical philosophy. We understand from Bar Hebraeus' statements above that Tusi for him was a mediatory 
figure who transferred Greek philosophy to him, as well as being his admired model, like Avicenna (Doru, 2017, p. 931).

Tusi had the broadest outlook, and this can be explained by the fact of his biography. He received a versatile education and was widely known in scientific circles in his youth. Later, in the prime of his young years, Tusi moved to Nishapur to continue his education.

He received his primary education from his father, a highly educated man. Already in his early years, he mastered the Quran. Then he began to study Arabic grammar - morphology, syntax, vocabulary, as well as jurisprudence. Then, under the guidance of his father, Tusi began to read prophetic hadiths, stories, learn fiqh and law. He studied logic and philosophy with his uncle, while studying natural science, theology, as well as mathematics, algebra, geometry and music.

Further, Tusi continues his education with various scientists - famous philosophers and faqihs of his time. His main teacher was the philosopher Farid al-Din Damadi al Nishapuri, known for his treatise "Kitabul Isharat". He taught Tusi the basics of logic. Damadi's mentor was Sadr ad-Din ibn Nasr at Sarakhsi, while Sarakhsi's mentor was Afzal ad-Din al-Gilani. Gilani's mentor was Abu-1-Abbas alLukri, the author of the book "Kitab-ul-badan al-haqq, who was a student of Bahmanyar. Bahmanyar's mentor was the great Ibn Sina. In the field of medicine and philosophy, Nasir al-Din al-Tusi studied with Qutb al-Din al-Misri, who was a student of Al-Fakhr ar-Razi, and studied Muslim jurisprudence with Sheikh Muin ad-Din.

At the same time, Nasir al-Din al-Tusi's mentor was Kamal ad-din ibn Yunis alMosuri, who excelled many scientists in the field of mathematics. Tusi was also among the students of Muin ad-Din Salim ibn Bidran al-Misri, the great scholar of imams. As some scholars mention, his mentor was al-Sheikh abu as Saadat al-Isfahani, while Tusi studied fiqh with Ibn Meisim al-Bahrani. In turn, Meisim learned philosophy from Nasir al-Din al-Tusi. Among the mentors of Tusi was Siraj ad-Din al-Kamri (Razavi, 1994, pp. 12-14).

In 1235, Tusi completed work on the treatise "Nasirean ethics (Akhlaki-Nasiri)", which he began to write at the request of the ruler of Kuhistan, which will be discussed below. By the end of the work, relations between the ruler and Tusi were strained, in connection with which in the same year Tusi was arrested and imprisoned in the Alamut fortress. Thus, he lived with the Assassins until 1256, that is, for more than 20 years, and it was during this period that he wrote his many famous works. In 1256 Hulagu Khan took the Alamut fortress and freed Nasir al-Din al-Tusi. In the preface to the Zij Ilkhani Astronomical Catalog, Mawlana writes the following: "At the time when Hulagu took over the command of the Assassin regions, I, the weak man, Nasir of Tus, was in the land of the Assassins. He freed me from there and ordered me to observe the stars..." (Maksudov \& Mammadbeyli, 1981, p. 21). Subsequently, Nasir al-din al-Tusi becomes one of the influential people at the court of Hulagu Khan - his vizier. 


\section{Maragheh Observatory.}

A colossal historical merit of the scientist is the founding of an astronomical observatory in the city of Maragha (1259-1260) (Bunyatov, 1982b, p. 73). Located on the territory of South Azerbaijan, it later became the largest scientific center of its era. This observatory had a huge impact on the development of astronomy in many countries. At the time mentioned, a decree was issued that "the great, happy Mawlana, teacher of the human race, the sultan of sages, the worthiest of the figures of recent times, Khoja Nasir al-Din al-Tusi, may the Lord embrace him with his forgiveness, build a place for observing the stars". Nasir al-Din al-Tusi arrived in Maragha with Hulagu Khan, who instructed him to build an observatory here. A high hill was chosen for the construction of the structure.

However, this episode was preceded by a number of other events. As Rashid addin narrates, "Mongke Khan [...] was distinguished by the perfection of his mind" and even "solved some Euclidean drawings. His excellent opinion and lofty thought were recognized as necessary for his state to build an observatory" (Rashid ad-Din, 2011, p. 68). However, some doubts arose among the people whom he entrusted with this business, while "the rumor about the excellent qualities of Nasir al-din flew around the world like the wind". Mongke Khan instructed Hulagu Khan to send him the Khoja Nasir al-Din al-Tusi. Nasir al-Din had long thought about building an observatory and was waiting for an opportunity (Razavi, 1994, p. 39). However, Hulagu khan decided that Nasir al-Din "was with him" and entrusted him with the construction of an observatory in Maragha. Hulagu Khan covered all the construction costs. Moreover, "he gave the scientist as much money as it was impossible to count" (Razavi, 1994, p. 46). At the same time, Hulagu invited several scientists-specialists in the field of mathematics, astronomy from different regions so that they help Tusi.

Thus, a magnificent observatory with an area of $150 \mathrm{~m} \times 350 \mathrm{~m}$ was built in Maragha (Rashid ad-Din, 1946, p. 48). The observatory began to be built in Yaum alsalis ar Rabia min jumad al-Ula in 657 (1259). The site was chosen in the upland part of the north-west of Maragha, known as Rasad Dagi (Jabal ar-Rasad). The first stone of the observatory was laid by Fakhr ad-Din Ahmad Osman Amin al-Maraghi (Razavi, 1994, p. 42). The observatory became one of the most famous for its time. Unfortunately, it survived only two generations, and after the first half of the 14th century, no one mentions it anymore. The remains of the observatory building have survived to this day (Seyidbeyli, 2015, p. 144). In 1990, Iranian archaeologists excavating in Alamut discovered the charred remains of this structure (Starr, 2017, p. 426).

According to sources, the Maragha (or Ilkhanid) observatory was built with the active participation of four scientists: Muayid ad-Din Urdi from Damascus, Fakhr adDin Maragi from Mosul, Fakhr ad-Khilat from Tiflis and Naji ad-Din al Dabirani Qazvini (Rashid ad-Din, 1946, p. 49). Another source notes that Tusi invited several scientists in the field of mathematics and astronomy for the construction. They are: Muayyid ad-din al Ardi from Damascus - a scientist in the field of geometry and 
instruments for the observatory, Najmaddin Dabirani al Katibi from Qazvin - a scientist in the field of philosophy and logic, Fakhr ad din al Akhlagi from Tiflis - an expert in mathematics, Fakhr ad din al Maraghi from Mosul - a doctor and mathematician, Naj ad din al Katib al Baghdadi, known as an expert mathematics, geometry, astronomy and drawing.

Mukhi ad-din al-Maghribi, a scientist in the field of mathematics and astronomy, Qutb ad din Shirazi, Shams ad din Shirvani, Sheikh Kamal ad din Idji, Husam ad din Shami, Najm ad din Shami, Najm ad-din al-Ustrulyabi, Ibn al-Fuwati, Seyid Rukn ad din al-Ustarabadi, Sadr ad din Ali, Asil ad din Hasan, son of Nasir ad-din Tusi and a number of others took part in the construction of the Maragha observatory (Razavi, 1994, p. 41).

Until the end of his life, Tusi supervised the scientific and administrative work of the observatory (Maksudov \& Mammadbeyli, 1981, p. 11). Only the information about the drawing up of the drawings of the Maragheh Observatory shows how comprehensive the nature of its activities was. Azerbaijani architects and researchers L. Bretanitsky and A. Salamzadeh suggested that Nasir al-Din al-Tusi was personally the author of the project of the Maragheh Observatory. Thus, the fact of his authorship of the observatory's drawings testifies to the closest connection between the architectural and construction activities of Tusi with his technical and mathematical knowledge.

Believing Nasir al-Din, Hulagu Khan invited specialists from China, who brought instruments with them. Also, Hulagu invited several scientists - specialists in the field of mathematics and astronomy - from different regions to help Nasir al-Din in the construction of the observatory (Razavi, 1994, pp. 40-41).

Thus, the first thing that is important to note here is the presence of a significant scientific potential of the era, concentrated within the walls of the observatory. Scientists of different nationalities worked under the leadership of Tusi. Most of them belonged to the number of major researchers who made an invaluable contribution to the development of science in their and subsequent eras.

Also, it should be emphasized: the observatory had a large number of instruments created here under the leadership of Tusi and distinguished by high quality. These instruments ensured greater accuracy in observations of the Sun, planets and various phenomena in the Universe. In total, 10 astronomical instruments were created here (Donirshoev, 1968). Among them were: 1. large wall quadrant; 2. armillary sphere; 3. as well as tools for determining the inclination of the ecliptic; 4 . a tool for determining the moments of the equinox; 5. tool for determining the size of the eclipse; 6 . Device for determining the horizontal coordinates of luminaries (rotating square); 7 . Tool with two pillars; 8 sine-instrument I (sine-azimuth instrument); 9. Sinus instrument II; 10. The perfect tool.

At the Maragheh Observatory, you can find other instruments for measuring time. For example: hourglass, water, oil clock. Also, at the observatory, earth and celestial globes were made and displayed for all to see, one of which has survived to this day. 
It was made by the son of Urdi Muhmammed and is today in the Mathematical-Physical Salon of Dresden State Art Collections. (Maksudov \& Mammadbeyli, 1981, pp. 200208). "Also, Nasir al-Din designed the astrolabe himself, having seen its image in any book" (Razavi, 1994, p. 45). With the passage of time, astronomical instruments in the Maragha observatory were used in various observatories of the world, among which the Tycho Brahe observatory, the Samarkand and Beijing observatories can be noted.

The third important factor that deserves attention is that a large team of researchers from Iran, Syria (Damascus) and the countries of the Caucasus and Central Asia, as well as from China and India, worked at the Maragheh Observatory. In total, more than 100 employees - prominent scientists and their students worked in the Maragheh Observatory and Library (Ibn al-Fuwati, 1962-1967, p. 19). The names of many of them have remained in history. These are: Muhammad Nasir al-Din al-Tusi, Qutb ad-Din Shirazi, Grigory Abul-Faraj (Bar-Ebrey - M. S.), Muayid-ad-din al-Urdi from Damascus, Najm ad-din Kazvini Dabirani al-Katib from Qazvin , Fakhr ad-din al-Akhlati from Tiflis, Fakhr ad-din al-Maragi from Mosul, Mohi ad-din Kamal Sheikh-Kamal, Najm ad-din Damgani Ustrlyabi, Husam ad-din Shami, Sadr ad-Din Nasir Tusi, Najm ad-din al-katib al-Baghdadi from Baghdad.

Many experts noted that the observatory will not be built earlier than in 30 years. Nasir al-Din al-Tusi built it much earlier (Razavi, 1994, p. 43). According to Rashid ad-din, its construction took 7 years (Rashid ad-Din, 1946, p. 48).

The result of 12-year (from 1259 to 1271) observations of the Maragha astronomers was the "Ilkhanic Tables (Zij Ilkhani)". This work contained tables for calculating the position of the sun and planets, as well as a star catalog. The tables contained a list of the geographical coordinates of 256 cities in the world. The uniqueness of the Maragheh Observatory lay in its location - an overview of all the stars opened from it. The library located at the Maragheh Observatory contained 400 thousand volumes of manuscripts in Arabic, Persian and Syriac in various fields of knowledge. To collect books, he sent people to different cities, and thus books were brought here from Baghdad, Damascus, Mosul, Khorasan, and other cities (Razavi, 1994, pp. 43-45).

The successor to the Maragha observatory was the observatory in Tabriz, founded by his student Qutb ad-din al-Shirazi (Rashid ad-Din, 1946, p. 48). Subsequently, the Maragheh Observatory had a huge scientific impact on the Beijing Observatory, built in the 13th century, as well as on the Ulugbek Observatory.

Thus, the Maragha Observatory, founded by Nasir al-Din al-Tusi, with its scientific potential, professional astronomical instruments, and the richest library, was the largest scientific center of the 13th century in the whole world. It was the "Academy of the Middle Ages".

\section{Scientific activity.}

As mentioned earlier, Nasir al-Din al-Tusi was a universal scholar and author of many essays. 
In the book by Muhammad Tagi Mudarris Razivi "The Life and Works of Nasir ad-din at-Tusi", the author mainly examines the works of Nasir al-din and indicates the location of copies of his works. In particular, he notes the names of 190 works of Nasir al-Din (Razavi, 1994, pp. 446-449), which are especially famous as scientific works on economics, philosophy, medicine, geography, astronomy, mineralogy, ethics, logic.

A special place among his works in the field of mathematics and astronomy is occupied by such works as the astronomical treatise "Thirty chapters on the knowledge of the calendar" (in Arabic and Persian versions) and "On the knowledge of the astrolabe" ("Dar Marifati-i Asturlab"). Among the most valuable mathematical and astronomical manuscripts is the manuscript No. 8990, rewritten in 1424 from the autograph of An-Naysaburi and dated 1265. This tome contains the following works of Tusi: "A predetermined treatise on astronomy" ("Risala al-mu'ayaniyya fi'ilm alhay'a") and an addition to it - "A collection of arithmetic with the help of a board and dust" ("Jami 'al-hisab bi-l takht wa at-turab"), "Thirty chapters on the knowledge of the calendar" ("Si fasl fi ma'rifat at-takvim"), as well as "commentary by al-Naisaburi to the last of the named treatises. This also includes an unknown in the literature essay "Treatise on the Calculus of Astronomers" ("Risala fi hisab al - munajimin") by Husayshah as Samnani (or al-Simnani, died in 1319), a poorly studied mathematician and astronomer of the Tusi circle, whose biography insufficiently studied. In history he is known, first of all, as the author of the commentary on the work "Zij Ilkhani" (Mammadbeyli, 1951, p. 37).

In the article by G. P. Matvievskaya and H. Tllashev, "New data on the scientific heritage of Nasir al-Din al-Tusi and his school", it is noted that "in the process of studying this manuscript, a list of Tusi's works was discovered, compiled, most likely, by his student An Naysaburi, and therefore which is of particular value for studying the scientific heritage of the great scientist". It lists 57 writings, many of which are not mentioned in the existing listings of Tusi's writings (Mammadbeyli, 1951, p. 37). Tusi's astronomical and mathematical works were very popular in the Near and Middle East, in China, India, and Western Europe.

His outstanding works such as "Zij Ilkhani”" (Tables of Elkhani), "Tahriri Eglidis" ("Presentation of Euclid"), "Shaklul Gita" (Treatise on the Complete Quadripartite), "Usturiyat" (Astrolabe) are classic works in the history of astronomy and mathematics (Mammadbeyli, 1951, p. 37).

The treatise by Tusi "Benefits in Algebra and Almukabal" ("Fawayid - and Tusi dar jabr wa mukabala") has not yet been studied. It gives the solution of 20 arithmetic and geometric problems by methods of algebra. The authors of the study of the scientific heritage of Tusi, G. P. Matvievskaya and H. Tllashev, proved that this treatise is one of the sections of Tusi's work "Treatise on Algebra and Almukabal". The manuscript of this treatise is in Damascus. "Exposition of the "Beginnings" of Euclid", "Collection on arithmetic with the help of blackboard and dust", "Treatise on the figure of secants", "Treatise on squaring the circle", "Algebraic fragment", "Presentation of the Books of Assumptions of Sabit ibn-Korra", "Arrangements by Tusi medium 
books", "Book of Euclid "Data", Book of Archimedes "Measurement of the circle", "Processing of the book of Archimedes "Lemma" (Rozhanskaya, Matvievskaya \& Lyuter, 1999).

In his essay "Tahrir Eglidis" ("Presentation of Euclid") Nasir al-Din al-Tusi writes: "I wrote this book after editing "Majesti". Indeed, in the list of copies in Arabic held in the Paris National Library, there is a mention of the book of Euclid. This is the Introduction of the Arabic text of Euclid, printed in Rome. There are many handwritten copies of this book, and they are available in many libraries. During Tusya's lifetime, one old and exquisitely designed copy of this book was published in one journal. Another copy, written in 772 (1322), is in the Higher Madrasah, in the Sipakhsalar library (Razavi, 1994, pp. 446-449).

Among the mathematical works of Tusi, the "Treatise on the Complete Quadripartite" occupies a significant place. The treatise was written in Persian during his stay at Alamut, and also in Arabic, in abridged form, at Maragha (1260). In "Collection of arithmetic with the help of a board and dust" (1265) by Tusi describes in detail the method of extracting a root of any degree using the example 2441400626. Methods for extracting a root with an arbitrary exponent and decomposing a binomial degree are described.

Among Tusi's works in the field of astronomy, I would like to mention his famous book "Zij Ilkhani" (“Astronomical Table of Elkhani"), which contains a catalog of bright stars and an extensive presentation, including geographic tables. This book consists of 4 parts: 1 - about chronology, 2 - about the knowledge of the movements of the stars (and planets), 3 - about the knowledge of time and the fate of each time, 4 - about other astronomical sciences. From "Zij Ilkhani" we learn the updated value of the total annual precession (Maksudov \& Mammadbeyli, 1981, p. 26). As already noted, the book is an astronomical catalog compiled as a result of 12 years of work by scientists at the Maragheh Observatory (from 1259 to 1271). It was the only astronomical catalog that existed for 200 years (up to the construction of the observatory by Ulug bek), from which scientists drew all the astronomical information necessary for compiling annual calendars and ephemeris (Abstracts of reports, 1951, p. 38).

In addition to issues of observational astronomy, Nasir al-Din al-Tusi was engaged in the theoretical side of the issue of planetary motion. One of his main works in this area, devoted to the theory of motion, is the book "A memo to astronomy". In addition to the above-mentioned works of Tusi, he also wrote the Treatise in "20 Chapters on the Knowledge of the Astrolabe" and "Treatise on the Sinus Quadrant".

The scientist also touched upon the problems of astronomy in a number of his treatises on physics. These are such works as "Processing", "Optics of Euclid", "Risola dar tahkiki kavsi kuzakh" ("Treatise on the study of the rainbow"), "Risola fil-kharorat wa-1 Barudat" ("Treatise on heat and cold"), "Risola dar bayoni subhi kozib" ("Treatise on dawn twilight"), "Risola dar kaifiyati zarurati harakat" ("Treatise on the 
circumstances of the necessity of movement"), Risola fi-l-hararat wa-l burudat (Reflection of the Light) (Dinorshoev, 1987, p. 34).

In addition to works related to mathematics and astronomy, Tusi's scientific heritage includes a large number of studies in the field of logic, philosophy and theology. I would like to note that Tusi knew Greek philosophy well. In his books, he has repeatedly given an objective assessment of the works of Aristotle, Plato, and also Porphyry - a famous Greek mathematician and logic of the Middle Ages (Seyidbeyli, 2015, p. 144).

Typically, medieval history is presented as the history of theology. Touching upon the religious and philosophical foundations of Tusi's evolutionary theory, I would like to note that the picture of the evolution of the world drawn by him corresponds to the ideology inherent in his time. On the one hand, the philosopher writes with admiration about the perfection of the surrounding world created by God, on the other, he recognizes the fact of self-development and self-improvement of matter. According to Tusi, nature as a whole and each creature individually are capable of developing and improving independently, but God inspires and directs this development. In other words, being once created by God, the world develops further by itself - according to the plan of the Creator (Seyidbeyli, 2015, p. 144).

In studying the issues of joint work in favor of society, N. Tusi paid great attention to the role of sociology. "The science of sociology is a theory about the real and general laws of the development of joint work aimed at the benefit of all. The object of this science is the system of human relations, people united by social labor, engaged in an improved form of production" (Tusi, 1989, pp. 228-229).

Among his other famous works are "Tazkira Nasir" ("Nasir's memory"), "Akhlaqi-Nasiri" (Nasirean ethics). The latter is still considered one of the best [in the spiritual heritage of the Middle Ages] as an example of fiction and philosophical literature. This treatise has been translated into many languages. It raises the problems of being, examines the philosophical aspects of the human character, examines the problems of good and evil.

In the book "Akhlaqi-Nasiri" ("Nasirean Ethics") Tusi outlined his ethical views, representing the new moral paradigms of his time. Here he raises the problem of being, the foundations of human behavior, but the main issue is the theme of human origin. According to Tusi, man is the highest product of evolution.

The work "Tajridul-etigad" ("On the proof of God and his attributes") is devoted to philosophy and the word. In the Introduction, Tusi says: "This book I have compiled in a good style and brought it into proper form. I have written in this book what I am convinced of. "Ultimately, this book can be used to judge the belief / attitude to the faith and religion of Tusi. "Tajridul-etigad" consists of 6 chapters. Chapter I deals with general issues, Chapter II is devoted to entities and their manifestations, Chapter III talks about the proof of the existence of God and his attributes, Chapter IV deals with the phenomenon of prophecy, and Chapter V deals with imams, finally, in the VI about the Day of Judgment and its proof (Razavi, 1994, pp. 446-449). 
In his work, N. Tusi attached great importance to science, scientific research, classification of sciences, the connection between science and life, as well as the role that science played in the development of mankind. All aspirations of scientific research, the scientist pointed out, should be aimed at the benefit of a person, at improving his well-being and achieving his well-being.

Nasir al-Din al-Tusi believed that each science has its own specific subject of study. This is what distinguishes various sciences from each other: according to the subject of study, they are classified as independent branches of knowledge. If some sciences have one common subject, then their classification as independent branches of knowledge depends on which side, which aspect of this subject they study

Nasir al-Din al-Tusi believed that each science has its own specific subject of study. This is what distinguishes various sciences from each other: according to the subject of study, they are classified as independent branches of knowledge. If some sciences have one common subject, then their classification as independent branches of knowledge depends on which side, which aspect of the given subject they study.

The scientist studied medical knowledge under Qutb ad-Din Misir. Having completed his studies in this area, he was well acquainted with the works of various doctors of that era. In particular, he wrote comments on the work of Ibn Sina "Medical Canon". At the same time, it is interesting to note his answers to questions in the books "Laws of Medicine", "Treatise on Medicine" (Risala at-Tibb). "Treatise on Medicine" consists of 2 parts.

Medical views of Tusi cover the issues of human hygiene and its relationship with purely medical problems, mainly in the field of the psyche. So, he divides human health into 4 groups, clearly defining the limits of each group. "Health is like moving in a straight line", the scientist writes, "and illness is a deviation from this line". N. Tusi distinguishes between physical and non-physical diseases. He classifies physical illnesses as follows: abnormality, stupidity, violence, fear, rabies, lethargy. The scientist gives a characteristic to each of these diseases. Along with physical illnesses, he considers the problem of moral health, which he subdivides into the following types and groups: mind, memory, resourcefulness.

\section{Conclusions.}

N. Tusi was a scientist-expert in many sciences of his time, especially such sciences as law, philosophy, kalam (scholasticism), logic, mathematical sciences, theology and astronomy, morality and ethics, etc., as well as some exact sciences. A large number of works were written by N. Tusi in the field of all the listed sciences. I would especially like to note the works written by him in the field of mathematics during his stay in Alamut (by the will of the Ismailis). After his release, he was engaged in very important state affairs in the palace of Hulagu Khan, and therefore he did not have the opportunity to translate and comment on his works.

Scientists and students from different parts of the world gathered around N. Tusi for the purpose of teaching. He perfectly knew the Arabic, Persian and Turkish 
languages and wrote his works freely in these languages. The books written by N. Tusi in these languages are very commendable in terms of literary language and eloquence. He wrote his book on science "Ramal" (a poem in the style of eruz) in three languages - Arabic, Persian and Turkish. Some researchers claim that N. Tusi wrote the book on the science "Ramal" in Turkish, and in subsequent years a certain scholar translated it into Persian. N. Tusi's works are very valuable and significant. Most of the famous scientists took useful thoughts from them and wrote comments to them. Many of his works have been translated into the leading languages of the world, including German, French, English, Latin, and published in European countries. The scholarly historians composing the inventory of his works were his contemporaries.

In 672, Nasir al-Din al-Tusi went to Baghdad accompanied by his friends and mentors. In the same year, he fell ill in Baghdad and died of illness. When Nasir ad din Tusi became ill and he felt that he was leaving the world, he wrote: "Do not carry me out of the tomb of the 7th Imam and bury me next to the tomb of His Lordship. And after he bequeathed to bury him next to the grave of Imam Kazim and Imam Javad, he asked not to write on his grave about his scientific and other merits: "On my tombstone, write only my name". In the same year he bequeathed to be buried next to the grave of Imam Kazim. He died in AH 672.

\section{References}

Abstracts of reports at the session dedicated to the 750th anniversary of the birth of the outstanding Azerbaijani scientist Muhammad Nasiraddin. (1951). Publishing house of the Academy of Sciences of Azerbaijan SSR [in Azerbaijani].

Tusi, K. N. (1989). Akhlagi-Nasiri [Nasir's ethics]. Baku: Elm Publishing House [in Arabic].

Bunyatov, Z. (1982a). Nasiraddin at-Tusi: Novie bioqraficheskie dannie [Nasiraddin at-Tusi: new biographical data]. Izvestiya Akademii Nauk Azerbaydjanskoy SSR. Seriya istorii, filosofii i prava - Bulletin of the Academy of Sciences of the Azerbaijan SSR. Series of history, philosophy and law, 2, 12-17 [in Russian].

Bunyatov, Z. (1982b). Nasir ad-din Muhammad at-Tusi i razvitie nauki v Azerbaydjane v XVIII veke [Nasir ad-din Muhammad at-Tusi and the development of science in Azerbaijan in the 18th century]. Izvestiya Akademii Nauk Azerbaydjanskoy SSR. Seriya istorii, filosofii i prava-Bulletin of the Academy of Sciences of the Azerbaijan SSR. Series of history, philosophy and law, 1, 70-75 [in Russian].

Dinorshoev, M. D. (1987). Filosofiya Nasiriddina Tusi [Philosophy of Nasreddin Tusi]. Dushanbe: Donish [in Russian].

Doru, M. N. (2017). The Influence of Islamic Philosophy on Bar Hebraeus (Abu'lFaraj Ibn Al-Ibrī). Cumhuriyet Ilahiyat Dergisi,21(2), 913-946. https://doi.org/10.18505/cuid.348938

Ibn al-Fuwati, K. al-Din (1962-1967). Talkhis Majma' al-Adab fi Mu'jam al-Alqab. Damascus [in Arabic] 
Maksudov, F. G., \& Mammedbejli, G. D. (1981). Muhammed Nasireddin Tusi [Mohammed Nasiraddin Tusi]. Baku: Gyandzhilik [in Russian].

Mammadbeyli, G. D. (1951). Znachenie nauchnyih trudov Muhammada Nasir ad-Dina $v$ razvitii astronomii i matematiki [The value of the scientific works of Muhammad Nasir al-Din in the development of astronomy and mathematics]. Baku: Izdatelstvo Akademii Nauk Azerbaydzhanskoy SSR [in Russian].

Razavi, M. T. (1994). Al-Alama al-havaji Nasiraddin at-Tusi. Life and work of the outstanding Nasir ad-Din at-Tusi. Astana: Mashhad [in Arabic].

Rashid ad-Din. (2011). Jami' al-tawarikh. Baku: Naghil evi [in Azerbaijani].

Rashid ad-Din. (1946). Sbornik Letopisei [Collection of Chronicles]. Moscow/Leningrad, Russia: Izdatel'stvo Akademii Nauk USSR [in Russian].

Rozhanskaya, M. M., Matvievskaya, G. P., \& Lyuter, I. O. (1999). Nasir ad-Din atTusi i ego trudy po matematike i astronomii v bibliotekah Sankt-Peterburga, Kazani, Tashkenta $i$ Dushanbe [Nasir ad-Din at-Tusi and his works on mathematics and astronomy in the libraries of St. Petersburg, Kazan, Tashkent and Dushanbe]. Moskva: Vostochnaya literature [in Russian].

Seyidbeyli, M. (2015). Rol Nasir ad-Dina at-Tusi v istorii nauki [The role of Nasir adDin at-Tusi in the history of science]. Institut istorii yestestvoznaniya i tekhniki im. S. I. Vavilova. Godichnaya nauchnaya konferentsiya. Vol. 1. Obshie problemi razvitiya nauki i tekhniki - Annual Scientific Conference of the RAS Institute of the History of Natural Science and Technology. Vol. 1. General problems of the development of science and technology. Moskva: Lenand [in Russian].

Starr, S. F. (2017). Utrachennoe Prosveshchenie: zolotoj vek Central'noj Azii ot arabskogo zavoevaniya do vremen Tamerlana [The Lost Enlightenment: The Golden Age of Central Asia from the Arab Conquest to the Time of Tamerlane]. Moskva: Alpino [in Russian].

\section{Марьям Сеідбейлі}

Інститут історії науки НАН Азербайджану, Азербайджан

\section{Життя і діяльність Насіра ад-Діна ат-Тусі}

Анотація. На початку VII століття в політичному житті Близького $i$ Середнього Сходу відбулися кардинальні зміни. Араби захопили колосальну територію, до якої увійшли землі Ірану, Північної Африки, Північно-Західної Індї̈, азіатські провінції Візантії, велика частина колишньої Римської імперії. У завойованих містах халіфату будувалися обсерваторії, медресе, бібліотеки. В кіниі VII століття в Багдаді був заснований перший науковий центр - академія - Будинок мудрості, в якому були зібрані вчені, які говорили на різних мовах. Тут була значно розвинена перекладацька і коментаторська діяльність. Протягом двох століть, з 750 по 950 роки, пращі античних авторів з філософії, математики, медицини, алхімії і астрономії переводилися на арабську мову, що 
свідчить про високий науковий потенціал того часу на Сході. Зокрема, Аверроес, який працював в ХІІ столітті склав 38 коментарів до працьь Аристотеля, «Республіки» Платона, трактату «Про розум» Олександра Афродізіаса, які згодом дуже вплинули на творчість Насір ад-Діна аль -Тусі. Таким чином, основні праці античної думки, такі як праці Аристотеля, Птолемея, були опубліковані в 9 столітті в арабомовному світі. Таким чином, ией період в історій східної наукової думки відзначений високим інтелектуальним потенціалом. До цзього дня історики середньовічної арабської наукової літератури стикаються з труднощуами, пов'язаними з тим, щуо переважна більшість рукописів залишаються для них недоступними. Роботам багатьох відомих арабських авторів середньовіччя більше 1000 років, тому представлясться очевидним, щзо рукописи переважної більшості авторів не збереглися до наших днів. Дослідники історії Азербайджану і сусідніх країн в середні століття, при всій різноманітності джерел, на які вони спираються, все щзе залучають мало фактичного матеріалу, пов'язаного з арабомовними творами історичного і наукового характеру. Безсумнівно, велике значення має комплексне вивчення всього обсягу відомостей, наявних в прачях Насір ад-Діна am-Tусі, з історії науки в Азербайджані.

Ключові слова: Насір ад-Дін ат-Тусі; історія науки; наукова діяльність; Мараге; астрономія

\section{Марьям Сеидбейли}

Институт истории науки НАН Азербайджана, Азербайджан

\section{Жизнь и деятельность Насира ад-Дина ат-Туси}

Аннотация. В начале VII века в политической жсизи Ближнего и Среднего Востока произошли кардинальные изменения. Арабы захватили колоссальную территорию, в которую воили земли Ирана, Северной Африки, СевероЗападной Индии, азиатские провинции Византии, большая часть бывшей Римской империи. В завоеванных городах халифата строились обсерватории, медресе, библиотеки. В коние VII века в Багдаде был основан первый научнылй центр - академия - Дом мудрости, в котором были собраны ученые, говорившие на разных языках. Здесь была значительно развита переводческая $u$ комментаторская деятельность. В течение двух столетий, с 750 nо 950 годы, труды античных авторов по философии, математике, медицине, алхимии и астрономии переводились на арабский язык, что свидетельствует о высоком научном потенцииале того времени на Востоке. В частности, работавиий в ХІІ веке Ибн Рушд составил 38 комментариев к трудам Аристотеля, «Республике» Платона, трактату «О разуме» Александра Афродизиаса, которые впоследствии оказали большое влияние на творчество Насир ад-Дина ат-Туси. Таким образом, основные труды античной мысли, такие как труды 
Аристотеля, Птолемея, были опубликованы в 9 веке в арабоязычном мире. Таким образом, этот период в истории восточной научной мысли отмечен высоким интеллектуальным потенщиалом. По сей день историки средневековой арабской научной литературы сталкиваются с трудностями, связанными с тем, что подавляющее большинство рукописей остаются для них недоступными. Работам многих известных арабских авторов средневековья более 1000 лет, поэтому представляется очевидным, что рукописи подавляющего больиинства авторов не сохранились до наших дней. Исследователи истории Азербайджана и соседних стран в средние века, при всем разнообразии источников, на которые они опираются, все еще привлекают мало фактического материала, связанного с арабоязычными произведениями исторического и научного характера. Несомненно, большое значение имеет комплексное изучение всего объема сведений, имеющихся в трудах Насир адДина ат-Туси, по истории науки в Азербайджане.

Ключевые слова: Насир ад-Дин ат-Туси; история науки; научная деятельность; Мараге; астрономия

Received 11.08.2020

Received in revised form 16.11.2020

Accepted 27.11.2020 